\title{
CHARACTERIZATION OF DENDRITIC-LIKE CELLS GENERATED FROM HEMATOPOIETIC SPLEEN CULTURES FROM ATLANTIC SALMON (SALMO SALAR L.)
}

\author{
Gyri T. Haugland ${ }^{\S}$, Harald S. Lunde, Charlotte F. Asserson and Heidrun I. Wergeland \\ Department of Biology, University of Bergen, Norway
}

\begin{abstract}
Dendritic cells (DCs) are the main organizers of the immune system in mammals bridging innate and adaptive immunity. DC-like cells are now also identified in teleost fish. At present there is little knowledge of fish DCs properties and functions due to lack of tools to isolate and analyze them. We have developed a protocol for generation of DC-like cells from hematopoietic spleen cultures from Atlantic salmon (Salmo salar L.). In the culture flasks, a stromal layer appeared and after 2 weeks incubation hematopoietic foci were formed. We will describe phenotype and morphology of both adherent and nonadherent $\mathrm{MHCII}^{+}$DC-like cells. Upon challenge with bacteria IL12p40, CD83 and CD80/86 were significantly upregulated in the non-adherent DC-like cells. These results support that the cells produced from the hematopoietic cultures are professional antigen cells with potential to activate naïve T-cells belonging to the dendritic cell linage.
\end{abstract}

\section{KEYWORDS}

§Corresponding author. Tel.: +47 55584445

E-mail address: Gyri.Haugland@uib.no 